\title{
Nitrogen management efficiency against sunflower (Helianthus annus L.) under different irrigation frequencies
}

\author{
Mumtaz Ali Gadehi ${ }^{1}$, Arshad Ali Kaleri ${ }^{2}$, Muhammad Waseem Kalro ${ }^{3}$, \\ Mukhtiar Hussain Mirjat ${ }^{4}$, Illahi Bux Bhatti ${ }^{5}$, Shazia Parveen Tunio ${ }^{6}$, \\ Mohsin Khan ${ }^{7}$ and Sajid Hussain Kaleri ${ }^{8 *}$ \\ 1. Senior Scientific Officer, SSRI (PARC) Tando Jam-Pakistan \\ 2. Departments of Plant Breeding and Genetics, Sindh Agriculture University Tando Jam-Pakistan \\ 3. Senior Scientific Officer, AZRI, PARC, Umerkot-Pakistan \\ 4. Department of Agricultural Education Extension and Short Courses, SAU Tando Jam-Pakistan \\ 5. Senior Scientific Officer, NSTHRI, PARC, Thatta-Pakistan \\ 6. Senior Scientific Officer, SSRI, PARC, Tando Jam-Pakistan \\ 7. Department of Biotechnology, Sindh Agriculture University Tando Jam-Pakistan \\ 8. Department of Soil Science, Sindh Agriculture University Tando Jam-Pakistan \\ *Corresponding author's email: Kalerisajid@gmail.com \\ Citation \\ Mumtaz Ali Gadehi, Arshad Ali Kaleri, Muhammad Waseem Kalro, Mukhtiar Hussain Mirjat, Illahi Bux Bhatti, \\ Shazia Parveen Tunio, Mohsin Khan and Sajid Hussain Kaleri. Nitrogen management efficiency against sunflower \\ (Helianthus annus L.) under different irrigation frequencies. Pure and Applied Biology. Vol. 6, Issue 2, pp576-584. \\ http://dx.doi.org/10.19045/bspab.2017.60059
}

Received: 17/02/2017 Revised: 05/04/2017

Accepted: 14/04/2017

Online First: 19/04/2017

\section{Abstract}

A field trial to examine nitrogen management efficiency against sunflower under varying irrigation frequencies was performed during 2015 at Agriculture Chemistry (Soils) Section, ARI Tandojam. Four $\mathrm{N}$ levels $\left(0,50,100,150 \mathrm{~kg} \mathrm{ha}^{-1}\right)$ and four irrigation frequencies $(2,3,4,5$ irrigations) were evaluated in RCBD with three replicates. The response of sunflower crop to varying $\mathrm{N}$ rates and irrigation frequency in relation to growth, seed yield and oil content was significant $(\mathrm{P}<0.05)$. Apart from the crop growth traits, sunflower seed yield was highest $\left(2520.90 \mathrm{kgha}^{-1}\right)$ with $41.73 \%$ oil content; while seed yield decreased to $2268.90 \mathrm{~kg} \mathrm{ha}^{-1}$ and oil content increased (42.09\%) under $100 \mathrm{~kg} \mathrm{ha}^{-1} \mathrm{~N}$ over $150 \mathrm{~kg} \mathrm{~N} \mathrm{ha}{ }^{-1}$. The $\mathrm{N} @ 50 \mathrm{~kg} \mathrm{ha}^{-1}$ remained least in all the growth and seed yield traits. Similarly, 04 times irrigated sunflower produced highest seed yield (2198.80 $\left.\mathrm{kg} \mathrm{ha}^{-1}\right)$ and oil content $(41.10 \%)$; while 05 times irrigated crop showed relatively lesser seed yield $\left(1953.40 \mathrm{~kg} \mathrm{ha}^{-1}\right)$ and oil content $(39.71 \%)$. The seed yield responded superbly to higher $\mathrm{N}\left(150 \mathrm{~kg} \mathrm{ha}^{-1}\right)$ with maximum seed yield $\left(2520.9 \mathrm{~kg} \mathrm{ha}^{-1}\right)$ but oil yield slightly decreased; while 04 times irrigated crop resulted in highest seed yield $\left(2198.8 \mathrm{~kg} \mathrm{ha}^{-1}\right)$ and oil content $(41.10 \%)$.

Keywords: Sunflower; Nitrogen efficiency; Irrigation frequency; Seed yield; Oil content

Introduction

Sunflower (Helianthus annuus L.) is a potential crop to bridge-up the gap between domestic demand and production [1] .In Pakistan, efforts are being made to enhance sunflower yields in addition to other 
conventional oilseed crops to overcome the edible oil deficit, because at least two sunflower crops in a year can be obtained (spring and autumn); and it is well adapted to existing agro-ecological conditions. During the year 2015-16, the total area under sunflower cultivation was 349 thousand hectares with seed production of 182 thousand tons and oil production of 69 thousand tons [2]. There are several causes that constrain potential crop yields and most of these are associated with the nutrient management flaws. Among nutrient management aspects, unoptimistic application of nitrogen has significant role in to influence the crop productivity in negative direction. Nutrient deficiency is one of the key factors to influence the crop productivity adversely. The universal deficiency of $\mathrm{N}$ has become more severe in regions of continuous cropping Nitrogen is the element of bio-molecules (amino acids, proteins, nucleic acids, phytohormones), enzymes as well as coenzymes. The plant growth is mainly stimulated by $\mathrm{N}$ availability in the soil. $\mathrm{N}$ also has key role in crop canopy expansion and solar radiation interception .The soil applied $\mathrm{N}$ is compulsory for achieving desired crop yields while as combined strategy of soil and foliar $\mathrm{N}$ application produces better nutrient utilization for yield production [3] suggested N@180 kg ha ${ }^{-1}$ through soil for obtaining higher seed and oil yields in sunflower. Similarly, irrigation management in relation to number of irrigations and scheduling of its application has very crucial role in crop production. Studies have demonstrated that avoiding irrigation during the vegetative growth stages could result decrease yields substantially and proper irrigation management could lead to improved irrigation water use efficiency. Most of the crops in Pakistan are produced under irrigated conditions; thus, it is essential to determine the water regimes leading to improved crop yields and irrigation efficiency. Hybrid cultivars having high seed cost give the highest yield only when irrigated .One of the needs of the hour is to adopt management techniques and technologies available for increasing irrigation efficiency. The purpose of irrigation scheduling is to determine the exact amount of water to apply to the field and the exact timing for application. The amount of water applied is determined by using a criterion to determine irrigation need and a strategy to prescribe how much water to apply in any situation. [3, 4] obtained maximum oil yield $\left(2213 / 22 \mathrm{~kg} \mathrm{ha}^{-}\right.$ 1) under $220 \mathrm{~kg} \mathrm{~N} \mathrm{ha}^{-1}$. [5] Obtained seed yield of $2415.68 \mathrm{~kg} \cdot \mathrm{ha}^{-1}$ with 4 irrigations. This study was mainly aimed at examining nitrogen management efficiency against sunflower variety Hysun-33 under varying irrigation frequency under field conditions.

\section{Materials and methods}

Sunflower hybrid Hysun-33 was cultivated in RCBD (factorial) with 03 replicates in 5.0 $\mathrm{X} 4 \mathrm{~m}\left(20 \mathrm{~m}^{2}\right)$ plot size at Agriculture Chemistry (Soils) Section, ARI Tandojam. Initially hard pan of the experimental soil was removed by running disc plow, followed by rotavator and finally precision land leveling carried out. Single coulter hand drill was used for sowing sunflower seeds in $60 \mathrm{~cm}$ apart rows and plant to plant space was maintained at $45 \mathrm{~cm}$ by thinning after 15 days of sowing to maintain the proper inter and intra row spacing. Four $\mathrm{N}$ levels $\left(0,50,100,150 \mathrm{~kg} \mathrm{ha}^{-1}\right)$ and four irrigation frequencies (2, 3, 4, 5 irrigations) were tested. All $\mathrm{P}$ and $\mathrm{K}$ in addition to $1 / 3^{\text {rd }}$ $\mathrm{N}$ were applied as basal dose at the sowing time; while remaining $\mathrm{N}$ was applied in two splits at first irrigation and at grain formation stage, respectively. $\mathrm{N}$ was applied as per the treatment plan; while $\mathrm{P}$ and $\mathrm{K}$ were applied at the rate of $100-50 \mathrm{~kg} \mathrm{ha}^{-1}$, respectively. Urea $(46 \% \mathrm{~N})$ was used for nitrogen and SSP for $\mathrm{P}$ and MOP for $\mathrm{K}$. 
Each fertilizer application was followed by irrigation and weeding was carried out manually. Five plants in each sub-plot were tagged for recording data on the traits related to crop growth, seed yield and oil content._For statistical analysis, the Statistix (ver. 8.1) computer software package was used to perform ANOVA for identifying the significance of treatment effect and DMRT (Duncan's Multiple Range Test) was performed to compare the treatment means as suggested by [6]

\section{Results and discussion}

\section{Germination (\%)}

The crop given highest $\mathrm{N}$ level of $150 \mathrm{~kg}$ ha ${ }^{1}$ resulted in highest germination of $79.96 \%$ and the germination reduced to 74.89 and $73.55 \%$ by decreasing $\mathrm{N}$ levels up to 100 and $50 \mathrm{~kg} \mathrm{ha}^{-1}$, respectively, while lowest germination $(72.49 \%)$ was observed in control (Table 1). In regards to effect of irrigation levels, the germination was highest $(77.32 \%)$, followed by 73.51 and $75.51 \%$ germination under 5 and 3 irrigations, respectively; while the lowest germination $(73.74 \%)$ was observed in plots given 2 irrigations. The interactive effect of $150 \mathrm{~kg} \mathrm{ha}^{-1} \mathrm{~N} \times 4$ irrigations resulted in maximum germination of $86.85 \%$ and minimum (72.04\%) under $0 \mathrm{~N} \times 2$ irrigations. The differences in germination percentage between 100,50 and $0 \mathrm{~kg} \mathrm{~N}^{-1}$ were non-significant $(\mathrm{P}>0.05)$, while differences in germination under 2 and 3 irrigations or 4 and 5 irrigations were also non-significant $(\mathrm{P}>0.05)$. This indicates that four irrigations would be enough to develop judiciousness of irrigation for sunflower crop, while increasing $\mathrm{N}$ level simultaneously improved the germination percentage in sunflower. These results are in agreement with those of [7] who reported that seed emergence improved with higher basal $\mathrm{N}$ application; applied $\mathrm{N}$ at 120 and $160 \mathrm{~kg} \mathrm{ha}^{-1}$ and given half as basal dose resulted in the highest germination in sunflower.

Table 1. Interactive effect of irrigation frequencies and $\mathrm{N}$ levels on seed germination, plant height, stem girth and head diameter of sunflower

\begin{tabular}{|l|c|c|c|c|}
\hline Factors & $\begin{array}{l}\text { Germination } \\
(\%)\end{array}$ & $\begin{array}{l}\text { Plant height } \\
(\mathbf{c m})\end{array}$ & $\begin{array}{l}\text { Stem girth } \\
(\mathbf{c m})\end{array}$ & $\begin{array}{l}\text { Head diameter } \\
(\mathbf{c m})\end{array}$ \\
\hline A-Irrigation levels (I) & $73.74^{\mathrm{b}}$ & $124.21 \mathrm{~d}$ & $4.96 \mathrm{c}$ & $14.22 \mathrm{~d}$ \\
\hline $\mathrm{I}_{1}=2$ irrigations & $75.51^{\mathrm{b}}$ & $131.69 \mathrm{c}$ & $5.26 \mathrm{~b}$ & $18.29 \mathrm{c}$ \\
\hline $\mathrm{I}_{2}=3$ irrigations & $77.32^{\mathrm{a}}$ & $140.68 \mathrm{~b}$ & $5.62 \mathrm{a}$ & $21.54 \mathrm{a}$ \\
\hline $\mathrm{I}_{3}=4$ irrigations & $73.51^{\mathrm{b}}$ & $155.32 \mathrm{a}$ & $5.51 \mathrm{a}$ & $29.34 \mathrm{~b}$ \\
\hline $\mathrm{I}_{4}=5$ irrigations & 1.5235 & 1.8618 & 0.0731 & 0.2281 \\
\hline$S . E . \pm$ & 3.1115 & 3.8023 & 0.1492 & 0.4659 \\
\hline$L S D 0.05$ & $72.49^{\mathrm{b}}$ & $104.13 \mathrm{~d}$ & $4.16 \mathrm{~d}$ & $13.39 \mathrm{~d}$ \\
\hline B-N levels (N) & $73.55^{\mathrm{b}}$ & $126.00 \mathrm{c}$ & $5.03 \mathrm{c}$ & $16.98 \mathrm{c}$ \\
\hline $\mathrm{N}_{1}=0 \mathrm{~kg} \mathrm{ha}^{-1}$ & $74.89^{\mathrm{b}}$ & $144.74 \mathrm{~b}$ & $5.78 \mathrm{~b}$ & $20.38 \mathrm{~b}$ \\
\hline $\mathrm{N}_{2}=50 \mathrm{~kg} \mathrm{ha}^{-1}$ & $79.96^{\mathrm{a}}$ & $177.02 \mathrm{a}$ & $6.38 \mathrm{a}$ & $22.64 \mathrm{a}$ \\
\hline $\mathrm{N}_{3}=100 \mathrm{~kg} \mathrm{ha}^{-1}$ & 1.5235 & 1.8618 & 0.0731 & 0.2281 \\
\hline $\mathrm{N}_{4}=150 \mathrm{~kg} \mathrm{ha}^{-1}$ & 3.8023 & 0.1492 & 0.4659 \\
\hline$S . E . \pm$ & 3.1115 & 93.74 & 3.75 & 10.50 \\
\hline$L S D 0.05$ & 72.04 & 113.43 & 4.53 & 13.13 \\
\hline Irrigation levels $\times \mathbf{N}$ levels & 74.10 & $\mathrm{I}_{1} \times \mathrm{N}_{1}$ & \multicolumn{5}{|l|}{} \\
\hline $\mathrm{I}_{1} \times \mathrm{N}_{2}$ & \multicolumn{5}{|l|}{} \\
\hline
\end{tabular}




\begin{tabular}{|l|c|c|c|c|}
\hline $\mathrm{I}_{1} \times \mathrm{N}_{3}$ & 73.63 & 130.30 & 5.21 & 15.75 \\
\hline $\mathrm{I}_{1} \times \mathrm{N}_{4}$ & 75.20 & 159.36 & 6.37 & 17.50 \\
\hline $\mathrm{I}_{2} \times \mathrm{N}_{1}$ & 72.18 & 99.39 & 3.97 & 13.50 \\
\hline $\mathrm{I}_{2} \times \mathrm{N}_{2}$ & 72.90 & 120.26 & 4.81 & 16.88 \\
\hline $\mathrm{I}_{2} \times \mathrm{N}_{3}$ & 73.77 & 138.15 & 5.52 & 20.26 \\
\hline $\mathrm{I}_{2} \times \mathrm{N}_{4}$ & 83.18 & 168.96 & 6.76 & 22.51 \\
\hline $\mathrm{I}_{3} \times \mathrm{N}_{1}$ & 73.36 & 106.17 & 4.24 & 15.29 \\
\hline $\mathrm{I}_{3} \times \mathrm{N}_{2}$ & 74.10 & 128.47 & 5.13 & 20.07 \\
\hline $\mathrm{I}_{3} \times \mathrm{N}_{3}$ & 74.99 & 147.57 & 5.90 & 24.08 \\
\hline $\mathrm{I}_{3} \times \mathrm{N}_{4}$ & 86.85 & 180.49 & 7.21 & 26.75 \\
\hline $\mathrm{I}_{4} \times \mathrm{N}_{1}$ & 72.37 & 117.22 & 4.68 & 14.29 \\
\hline $\mathrm{I}_{4} \times \mathrm{N}_{2}$ & 73.09 & 141.84 & 5.67 & 17.85 \\
\hline $\mathrm{I}_{4} \times \mathrm{N}_{3}$ & 73.97 & 162.93 & 6.51 & 21.43 \\
\hline $\mathrm{I}_{4} \times \mathrm{N}_{4}$ & 74.62 & 199.27 & 5.18 & 23.80 \\
\hline$S . E . \pm$ & 3.0470 & 3.7236 & 0.1461 & 0.4562 \\
\hline$L S D 0.05$ & $n$ & $n s$ & 0.2985 & 0.9317 \\
\hline
\end{tabular}

\section{Plant height (cm)}

The sunflower crop fertilized with highest $\mathrm{N}$ level of $150 \mathrm{~kg} \mathrm{ha}^{-1}$ resulted in maximum plant height of $177.02 \mathrm{~cm}$ and the plant height significantly decreased to 144.74 and $126.00 \mathrm{~cm}$ by decreasing $\mathrm{N}$ levels up to 100 and $50 \mathrm{~kg} \mathrm{ha}^{-1}$, respectively, while the lowest plant height $(104.13 \mathrm{~cm})$ was noted in control (Table 1). The effect of irrigation levels indicated that the plant height was maximum $(155.32 \mathrm{~cm})$ when given 5 irrigations, followed by 140.68 and 131.69 $\mathrm{cm}$ plant height under 4 and 3 irrigations, respectively; while the minimum plant height $(124.21 \mathrm{~cm})$ was noted in plots given only 2 irrigations. The interactive effect of $150 \mathrm{~kg} \mathrm{ha}^{-1} \mathrm{~N} \times 5$ irrigations resulted in maximum plant height of $199.27 \mathrm{~cm}$ and minimum $(93.74 \mathrm{~cm})$ under $0 \mathrm{~N} \times 2$ irrigations. The results showed that with each increased level of $\mathrm{N}$ significantly $(\mathrm{P}<0.05)$ increased the plant height; and similarly with each increase irrigation, the plant height showed a parallel improvement. There were linear and significant $(\mathrm{P}<0.05)$ differences in plant height among all the $\mathrm{N}$ levels as well as irrigation levels. Hence, for plant height, five irrigations and $150 \mathrm{~kg} \mathrm{~N}$ $\mathrm{ha}^{-1}$ proved to be more effective in increasing plant height as compared to rest of the treatments.

Stem girth (cm)

The crop supplied with highest $\mathrm{N}$ level of $150 \mathrm{~kg} \mathrm{ha}^{-1}$ resulted in maximum stem girth of $6.38 \mathrm{~cm}$ which reduced to $5.78 \mathrm{~cm}$ and $5.03 \mathrm{~cm}$ by decreasing $\mathrm{N}$ levels up to 100 and $50 \mathrm{~kg} \mathrm{ha}^{-1}$, respectively, the lowest stem girth $(4.16 \mathrm{~cm})$ was found in control (Table 1). The effect of irrigation levels showed that the stem girth was maximum $(5.62 \mathrm{~cm})$ when given 4 irrigations, followed by 5.51 $\mathrm{cm}$ and $5.26 \mathrm{~cm}$ stem girth under 5 and 3 irrigations, respectively; while the minimum stem girth $(4.96 \mathrm{~cm})$ was observed in plots given only 2 irrigations. The interactive effect of $150 \mathrm{~kg} \mathrm{ha}^{-1} \mathrm{~N} \times 4$ irrigations resulted in maximum stem girth of $7.21 \mathrm{~cm}$ and minimum $(3.75 \mathrm{~cm})$ under $0 \mathrm{~N} \times 2$ irrigations. The results indicated that with each increased level of $\mathrm{N}$, the stem girth was improved significantly $(\mathrm{P}<0.05) ; \quad$ and similarly increasing irrigations up to 4 , resulted in an improvement in stem girth, and adverse effect on stem girth was observed when irrigation increased to 5 . Linear and significant $(\mathrm{P}<0.05)$ differences in stem girth among all the $\mathrm{N}$ levels were noted; while differences in stem girth 
between 5 and 4 irrigations were nonsignificant $(\mathrm{P}>0.05)$. Hence, for stem girth, four irrigations and $150 \mathrm{~kg} \mathrm{~N}^{-1}$ would be the optimum treatment combination for achieving desired results for this trait of sunflower.

\section{Head diameter $(\mathbf{c m})$}

The crop fertilized with highest $\mathrm{N}$ level of $150 \mathrm{~kg} \mathrm{ha}^{-1}$ resulted in maximum head diameter of $22.64 \mathrm{~cm}$, followed by $20.38 \mathrm{~cm}$ and $16.98 \mathrm{~cm}$ head diameter observed under $\mathrm{N}$ levels of 100 and $50 \mathrm{~kg} \mathrm{ha}^{-1}$, respectively (Table 1). The lowest head diameter (13.39 $\mathrm{cm})$ was recorded in control. The irrigation effect showed that the head diameter was maximum $(21.54 \mathrm{~cm})$ when the crop was irrigated 4 times, followed by $19.34 \mathrm{~cm}$ and $18.29 \mathrm{~cm}$ mean head diameter determined in crop given 5 and 3 irrigations, respectively. However, the lowest head diameter (14.22 $\mathrm{cm})$ was recorded in plots irrigated 2 times only. The interactive effect of $150 \mathrm{~kg} \mathrm{ha}^{-1} \mathrm{~N}$ $\times 4$ irrigations resulted in maximum head diameter of $26.75 \mathrm{~cm}$ and minimum (10.50 $\mathrm{cm})$ under treatment interaction of $0 \mathrm{~N} \times 2$ irrigations. There was consecutive increase in the head diameter with increasing $\mathrm{N}$ up to $150 \mathrm{~kg} \mathrm{ha}^{-1}$; while head diameter followed successive increase up to 4 irrigations and later decreased. Significant $(\mathrm{P}<0.05)$ difference in head diameter among all the $\mathrm{N}$ levels as well as irrigation levels was assessed. However, irrigating crop five times resulted in excess soil water moisture and head diameter affected adversely under five irrigations. Thus, for achieving desired results in head diameter, four irrigations and $150 \mathrm{~kg} \mathrm{~N} \mathrm{ha}{ }^{-1}$ would be the optimum treatment combination in sunflower.

\section{Seeds head ${ }^{-1}$}

The sunflower crop given highest $\mathrm{N}$ level of $150 \mathrm{~kg} \mathrm{ha}^{-1}$ produced maximum seeds head ${ }^{-1}$ (2038.00), followed by 1834.20 and 1528.50 seeds head ${ }^{-1}$ noted in plots given $\mathrm{N}$ at the rates of 100 and $50 \mathrm{~kg} \mathrm{ha}^{-1}$, respectively (Table 2). The lowest seeds head ${ }^{-1}$ (1205.70) was recorded in control. In irrigation treatment, the seeds head ${ }^{-1}$ was maximum (1939.20) when the crop was irrigated 4 times, followed by 1740.90 and 1646.30 seeds head ${ }^{-1}$ found in crop given 5 and 3 irrigations, respectively. However, the minimum seeds head ${ }^{-1}$ (1279.90) was recorded in plots irrigated 2 times only. The interactive effect of $150 \mathrm{~kg} \mathrm{ha}^{-1} \mathrm{~N} \times 4$ irrigations resulted in maximum seeds head ${ }^{-1}$ of 2407.80 and minimum (945.20) in treatment interaction of $0 \mathrm{~N} \times 2$ irrigations. There was consecutive increase in the seeds head $^{-1}$ with increasing $\mathrm{N}$ up to $150 \mathrm{~kg} \mathrm{ha}^{-1}$; while seeds head ${ }^{-1}$ also increase successively up to 4 irrigations and decreased in 5 irrigations. The crop receiving five irrigations followed a decreasing trend in seeds head $^{-1}$ under five irrigations; which suggested that irrigating sunflower crop more than four times will not be beneficial for this trait. Thus, for achieving desired results in seeds head ${ }^{-1}$, the crop may be fertilized with $150 \mathrm{~kg} \mathrm{~N}^{-1}$ and should be irrigated four times during whole growth period. 
Table 2. Interactive effect of irrigations and $\mathrm{N}$ levels on seeds head ${ }^{-1}$, seed weight head ${ }^{-1}(\mathrm{~g})$, seed index (g), seed yield $\left(\mathrm{kg} \mathrm{ha}^{-1}\right)$, oil content $(\%)$ of sunflower

\begin{tabular}{|c|c|c|c|c|c|}
\hline Factors & Seeds head $^{-1}$ & $\begin{array}{l}\text { Seed weight } \\
\text { head }^{-1}(\mathrm{~g})\end{array}$ & \begin{tabular}{|l}
$\begin{array}{l}\text { Seed index } \\
\text { (g) }\end{array}$ \\
\end{tabular} & \begin{tabular}{|l} 
Seed yield \\
$\left(\mathrm{kg} \mathrm{ha}^{-1}\right)$
\end{tabular} & $\begin{array}{l}\text { Oil content } \\
(\%)\end{array}$ \\
\hline \multicolumn{6}{|c|}{ A-Irrigation levels (I) } \\
\hline$I_{1}=2$ irrigations & $1279.90 \mathrm{~d}$ & $40.46 \mathrm{~d}$ & $32.77 \mathrm{~d}$ & $1454.00 \mathrm{~d}$ & $38.00 \mathrm{~d}$ \\
\hline$I_{2}=3$ irrigations & $1646.30 \mathrm{c}$ & $51.44 \mathrm{c}$ & $41.67 \mathrm{c}$ & $1836.50 \mathrm{c}$ & $38.14 \mathrm{c}$ \\
\hline$I_{3}=4$ irrigations & $1939.20 \mathrm{a}$ & $60.60 \mathrm{a}$ & $49.08 \mathrm{a}$ & $2198.80 \mathrm{a}$ & $41.10 \mathrm{a}$ \\
\hline $\mathrm{I}_{4}=5$ irrigations & $1740.90 \mathrm{~b}$ & $54.40 \mathrm{~b}$ & $44.06 \mathrm{~b}$ & $1953.40 \mathrm{~b}$ & $39.71 \mathrm{~b}$ \\
\hline S.E. \pm & 29.793 & 0.6354 & 0.5507 & 35.508 & 0.0336 \\
\hline$L S D 0.05$ & 60.846 & 1.2977 & 1.1248 & 72.516 & 0.0686 \\
\hline \multicolumn{6}{|l|}{ B-N levels (N) } \\
\hline $\mathrm{N}_{1}=0 \mathrm{~kg} \mathrm{ha}^{-1}$ & $1205.70 \mathrm{~d}$ & $38.13 \mathrm{~d}$ & $30.89 \mathrm{~d}$ & $762.15 \mathrm{~d}$ & $35.82 \mathrm{~d}$ \\
\hline $\mathrm{N}_{2}=50 \mathrm{~kg} \mathrm{ha}^{-1}$ & $1528.50 \mathrm{c}$ & $47.76 \mathrm{c}$ & $38.69 \mathrm{c}$ & $1890.70 \mathrm{c}$ & $38.13 \mathrm{c}$ \\
\hline $\mathrm{N}_{3}=100 \mathrm{~kg} \mathrm{ha}^{-1}$ & $1834.20 \mathrm{~b}$ & $57.31 \mathrm{~b}$ & $46.42 \mathrm{~b}$ & $2268.90 \mathrm{~b}$ & $42.09 \mathrm{a}$ \\
\hline $\mathrm{N}_{4}=150 \mathrm{~kg} \mathrm{ha}^{-1}$ & $2038.00 \mathrm{a}$ & $63.68 \mathrm{a}$ & $51.58 \mathrm{a}$ & $2520.90 \mathrm{a}$ & $41.73 \mathrm{~b}$ \\
\hline S.E. \pm & 29.793 & 0.6354 & 0.5507 & 35.508 & 0.0336 \\
\hline$L S D 0.05$ & 60.846 & 1.2977 & 1.1248 & 72.516 & 0.0686 \\
\hline \multicolumn{6}{|c|}{ Irrigation levels $\times$ N levels } \\
\hline $\mathrm{I}_{1} \times \mathrm{N}_{1}$ & \begin{tabular}{|l|l|}
945.20 \\
\end{tabular} & 31.38 & 25.42 & 652.20 & 34.62 \\
\hline $\mathrm{I}_{1} \times \mathrm{N}_{2}$ & 1181.50 & 36.92 & 29.90 & 1461.50 & 36.70 \\
\hline $\mathrm{I}_{1} \times \mathrm{N}_{3}$ & 1417.80 & 44.30 & 35.88 & 1753.80 & 40.51 \\
\hline $\mathrm{I}_{1} \times \mathrm{N}_{4}$ & 1575.30 & 49.23 & 39.87 & 1948.60 & 40.16 \\
\hline $\mathrm{I}_{2} \times \mathrm{N}_{1}$ & 1215.70 & 37.99 & 30.77 & 703.80 & 35.66 \\
\hline $\mathrm{I}_{2} \times \mathrm{N}_{2}$ & 1519.70 & 47.49 & 38.46 & 1879.80 & 37.80 \\
\hline $\mathrm{I}_{2} \times \mathrm{N}_{3}$ & 1823.60 & 56.98 & 46.15 & 2255.80 & 41.72 \\
\hline $\mathrm{I}_{2} \times \mathrm{N}_{4}$ & 2026.20 & 63.32 & 51.29 & 2506.40 & 41.37 \\
\hline $\mathrm{I}_{3} \times \mathrm{N}_{1}$ & 1376.20 & 43.00 & 34.83 & 902.40 & 37.45 \\
\hline $\mathrm{I}_{3} \times \mathrm{N}_{2}$ & 1805.80 & 56.43 & 45.71 & 2233.80 & 39.69 \\
\hline $\mathrm{I}_{3} \times \mathrm{N}_{3}$ & 2167.00 & 67.72 & 54.85 & 2680.60 & 43.81 \\
\hline $\mathrm{I}_{3} \times \mathrm{N}_{4}$ & 2407.80 & 75.24 & 60.29 & 2978.30 & 43.44 \\
\hline $\mathrm{I}_{4} \times \mathrm{N}_{1}$ & 1285.60 & 40.77 & 32.54 & 790.20 & 36.18 \\
\hline $\mathrm{I}_{4} \times \mathrm{N}_{2}$ & 1607.00 & 50.21 & 40.67 & 1987.80 & 38.35 \\
\hline $\mathrm{I}_{4} \times \mathrm{N}_{3}$ & 1928.30 & 60.26 & 48.81 & 2385.40 & 42.33 \\
\hline $\mathrm{I}_{4} \times \mathrm{N}_{4}$ & 2142.60 & 66.95 & 54.23 & 2650.40 & 41.97 \\
\hline S.E. \pm & 59.586 & 1.2709 & 1.1015 & 71.015 & 0.0672 \\
\hline$L S D 0.05$ & 121.69 & 2.5954 & 2.2495 & 145.03 & 0.1373 \\
\hline
\end{tabular}

\section{Seed weight head ${ }^{-1}$}

The crop fertilized with highest $\mathrm{N}$ level of $150 \mathrm{~kg} \mathrm{ha}^{-1}$ produced highest seed weight head $^{-1}(63.688 \mathrm{~g})$, followed by 57.31 and $47.76 \mathrm{~g}$ seed weight head ${ }^{-1}$ observed in plots given $\mathrm{N}$ at the rates of 100 and $50 \mathrm{~kg} \mathrm{ha}^{-1}$, respectively (Table 2). The lowest seed weight head ${ }^{-1}(38.13 \mathrm{~g})$ was recorded in control. In case of irrigations, the seed weight head ${ }^{-1}$ was maximum $(60.60 \mathrm{~g})$ when the crop was irrigated 4 times, followed by $54.40 \mathrm{~g}$ and $51.44 \mathrm{~g}$ seed weight head ${ }^{-1}$ found in crop given 5 and 3 irrigations, respectively. However, the lowest seed 
weight head ${ }^{-1}$ (40.46 g) was obtained in plots irrigated 2 times only. The interactive effect of $150 \mathrm{~kg} \mathrm{ha}^{-1} \mathrm{~N} \times 4$ irrigations resulted in maximum seed weight head ${ }^{-1}$ of $75.24 \mathrm{~g}$ and minimum (31.38 g) in treatment interaction of $0 \mathrm{~N} \times 2$ irrigations. There was consecutive increase in seed weight head ${ }^{-1}$ with increasing $\mathrm{N}$ up to $150 \mathrm{~kg} \mathrm{ha}^{-1}$; while seed weight head $^{-1}$ also increased with consecutive increase in irrigations up to 4 irrigations and decreased when crop was irrigated five times. The seed weight head ${ }^{-1}$ showed a linear and significant difference among $\mathrm{N}$ levels and irrigation levels; but five irrigations did not prove beneficial even negative effect on this trait was observed. Hence, sunflower crop may be fertilized with $150 \mathrm{~kg} \mathrm{~N} \mathrm{ha}^{-1}$ under four irrigations during for achieving higher seed weight head $^{-1}$.

\section{Seed index (g)}

The seed index was highest (51.58 g) in crop given highest $\mathrm{N}$ level of $150 \mathrm{~kg} \mathrm{ha}^{-1}$, followed by $46.42 \mathrm{~g}$ and $38.69 \mathrm{~g}$ seed index noted in plots given $\mathrm{N}$ at the rates of 100 and $50 \mathrm{~kg} \mathrm{ha}^{-1}$, respectively (Table 2). The lowest seed index (30.89 g) was recorded in control. In case of irrigation levels, the seed index was maximum (49.08 g) when the crop was irrigated 4 times, followed by $44.06 \mathrm{~g}$ and $41.67 \mathrm{~g}$ seed index found in crop given 5 and 3 irrigations, respectively. However, the lowest seed index (32.77 g) was noted in plots irrigated 2 times only. The interactive effect of $150 \mathrm{~kg} \mathrm{ha}^{-1} \mathrm{~N} \times 4$ irrigations resulted in maximum seed index of $60.29 \mathrm{~g}$ and minimum $(25.42 \mathrm{~g})$ in treatment interaction of $0 \mathrm{~N} \times 2$ irrigations. There was constant improvement in seed index with each increment in $\mathrm{N}$ up to $150 \mathrm{~kg}$ $\mathrm{ha}^{-1}$; while seed index also increased with consecutively with increasing irrigations up to 4 irrigations and decreased when crop was irrigated five times. The differences in seed index under different $\mathrm{N}$ levels and irrigation frequencies were linear and significant $(\mathrm{P}<0.05)$; but adverse effects on seed index were observed under five irrigations, showing excessiveness of water. Thus, sunflower crop may be given $\mathrm{N}$ at the rate of $150 \mathrm{~kg} \mathrm{~N} \mathrm{ha}^{-1}$ and irrigated four times throughout the season.

\section{Seed yield ha ${ }^{-1}$}

The crop fertilized with highest $\mathrm{N}$ level of $150 \mathrm{~kg} \mathrm{ha}^{-1}$ produced highest seed yield ha-1 $(2520.90 \mathrm{~kg})$, followed by seed yield of 2268.90 and $1890.70 \mathrm{~kg} \mathrm{ha}^{-1}$ observed in plots given $\mathrm{N}$ at the rates of 100 and $50 \mathrm{~kg}$ $\mathrm{ha}^{-1}$, respectively (Table 2). The lowest seed yield $\mathrm{ha}^{-1}(762.15 \mathrm{~kg})$ was recorded in control. In case of irrigations, the seed yield $\mathrm{ha}^{-1}$ was highest $(2198.80 \mathrm{~kg})$ when the crop was irrigated 4 times, followed by $1953.40 \mathrm{~g}$ and $1836.50 \mathrm{~kg}$ seed yield $\mathrm{ha}^{-1}$ found in crop given 5 and 3 irrigations, respectively. However, the lowest seed yield $\mathrm{ha}^{-1}$ $(1454.00 \mathrm{~kg})$ was obtained in plots given only 2 irrigations. The interactive effect of $150 \mathrm{~kg} \mathrm{ha}^{-1} \mathrm{~N} \times 4$ irrigations produced highest seed yield of $2978.30 \mathrm{~kg} \mathrm{ha}^{-1}$ and minimum $\left(652.20 \mathrm{~kg} \mathrm{ha}^{-1}\right)$ in treatment interaction of $0 \mathrm{~N} \times 2$ irrigations. This higher seed yield under higher $\mathrm{N}$ levels and irrigated four times was mainly associated with higher stem girth, head diameter, seeds head $^{-1}$, seed weight head ${ }^{-1}$ and seed index value. It was observed that with increasing $\mathrm{N}$ the seed yield increased considerably and $150 \mathrm{~kg} \mathrm{ha}^{-1} \mathrm{~N}$ proved to be beneficial; but in irrigations, five irrigations resulted adverse effects on the crop, and crop irrigated four times produced higher seed yields than rest of the treatments. This indicates excessiveness of irrigation water to sunflower if applied more than four times throughout the growing season.

\section{Oil content (\%)}

The oil content was highest $(42.09 \%)$ when the crop was fertilized with $100 \mathrm{~kg} \mathrm{ha}^{-1} \mathrm{~N}$, followed by oil content of 41.73 and $38.13 \%$ determined in plots given $\mathrm{N}$ at the rates of 150 and $50 \mathrm{~kg} \mathrm{ha}^{-1}$, respectively (Table 2). 
The lowest oil content (35.98\%) was recorded in control. In case of irrigations, the oil content was highest $(41.10 \%)$ when the crop was irrigated 4 times, followed by $39.71 \%$ and $39.14 \%$ determined in crop given 5 and 3 irrigations, respectively. However, the lowest oil content $(38.00 \%)$ was obtained in plots given only 2 irrigations. The interactive effect of $150 \mathrm{~kg}$ ha $^{-1} \mathrm{~N} \times 4$ irrigations produced highest oil content of $43.81 \%$ and minimum $(34.62 \%)$ in treatment interaction of $0 \mathrm{~N} \times 2$ irrigations. It was observed that the yield content in sunflower decreased when $\mathrm{N}$ was applied beyond $100 \quad \mathrm{~kg} \mathrm{ha}^{-1}$, which suggested that due to increasing growth excessively under $150 \mathrm{~kg} \mathrm{~N}^{-1}$, the oil content is adversely affected. On the other hand, under five irrigations, the oil content decreased considerably over four irrigations, which suggested that this trait is adversely affected under excessive water application. Hence, it is assumed that for achieving higher oil content in sunflower, the crop may be fertilized with $100 \mathrm{~kg} \mathrm{~N}^{-1}$ along with recommended $\mathrm{P}$ and $\mathrm{K}$ and four irrigations would be enough to fulfill the needs of the crop for oil content percentage under good management conditions.

[7] reported that plant height, head diameter, dry matter, grain yield of sunflower and total consumptive use increased with increasing irrigation and $\mathrm{N}$ rate. The average water use efficiency decreased with increasing irrigation but increased with increasing $\mathrm{N}$ rate. Both treatments had no significant effects on the mean 100-grain weight. The interaction effects of irrigation and $\mathrm{N}$ application had no significant effects on the parameters measured. Similarly, [8] evaluated the effect of irrigation frequencies i.e. $0,2,4,6$ and 8 and concluded that parameters like plant height, head diameter, number of grains per head, 1000-grain weight and grain yield per hectare were significantly affected by irrigation levels and six irrigations were found optimum for obtaining good yield of sunflower. On the basis of research findings, six irrigations are recommended for sunflower crop to obtain maximum seed yield under irrigated conditions. Similarly [9] found that water use efficiency were higher at 1 irrigation, however, 3 irrigations resulted in higher net returns. [10] Reported that proper scheduling of irrigation resulted in significantly maximum sunflower seed yield of $1391.7 \mathrm{~kg} \mathrm{ha}^{-1}$ and response of plant height, diameter, seeds per head or seed weight of sunflower was found to be linearly related to the amount of irrigation. [7] Reported that average water use efficiency decreased with increasing irrigation but increased. Considerable research has been reported from different parts of the world in relation to water use efficiency in sunflower. [11] Concluded that under limited water conditions provide irrigations at bud stage and grain formation stage. If there is water sufficient for only are irrigation, irrigation should be scheduled only at flowering. Similarly [12] reported that seed yield with three or four irrigations was $24.83 \%$ higher than the control plot.

\section{Conclusions}

It was concluded that yield and yield components responded superbly to higher $\mathrm{N}$ level of $150 \mathrm{~kg} \mathrm{ha}^{-1}$ with maximum seed yield of $2520.9 \mathrm{~kg} \mathrm{ha}^{-1}$, but the oil content was slightly decreased. Moreover, the crop irrigated four times resulted in highest seed yield $\left(2198.8 \mathrm{~kg} \mathrm{ha}^{-1}\right)$ and oil content (41.10\%) which decreased when crop irrigated five times. Hence, the interaction of the $150 \mathrm{~kg} \mathrm{ha}^{-1} \mathrm{~N} \times 4$ irrigations would be an effective treatment combination to produce higher seed yield ha ${ }^{-1}$ in sunflower. The oil content was highest (42.09\%) when the crop was fertilized with $100 \mathrm{~kg} \mathrm{ha}^{-1} \mathrm{~N}$, followed by oil content of 41.73 and $38.13 \%$ determined in plots given $\mathrm{N}$ at the rates of 150 and $50 \mathrm{~kg} \mathrm{ha}^{-1}$ respectively. 


\section{Authors' contributions}

Conceived and designed the experiments: MA Gadehi \& AA Kaleri, Performed the Experiments: MA Gadehi \& SH Kaleri, Analyzed the Data: MA Gadehi \& MW Kalro, Contributed reagents/ materials/ analysis tools: MH Mirjat, IB Bhatti \& SP Tunio, Wrote the paper: MA Gadehi \& AA Kaleri.

\section{References}

1. Ahmad R \& Jabeen N (2009). Demonstration of growth improvement in sunflower (Helianthus annuus L.) by the use of organic fertilizers under saline conditions. Pak J Bot 41(3): 1373-1384.

2. GOP (2013). Economic Survey of Pakistan, 2012-2013. Government of Pakistan, Ministry of Food, Agriculture and Livestock, Agriculture \& Livestock Division (Economic Wing), Islamabad.

3. Nasim, W, Ahmad A, Hammad HM, Chaudhary HJ \& Munis MFH (2012). Effect of nitrogen on growth and yield of sunflower under semi-arid conditions of Pakistan. Pakistan Journal of Botany 44(2): 639-648.

4. Gholinezhad E, Aynaband A, Ghorthapeh $\mathrm{AH}, \quad$ NOORNOHAMADI $\mathrm{G}$ \& Bernousi I (2011). Effect of drought and nitrogen rates on grain yield, quality traits and physiological indices in sunflower hybrid Iroflor at different plant density. World Applied Sciences Journal 14(1): 131-139.

5. Ali A \& Noorka IR (2013). Differential growth and development response of sunflower hybrid in contrasting irrigation regimes. American Journal of Plant Sciences 4: 1060-1065.
6. Gomez KA \& Gomez AA (1984). Statistics for Agricultural Research (Second Edition). John Willey and Sons, New York.

7. Singh S \& Sidhu MS (2004). Integrated use of organic and inorganic fertilizer sources in hybrid sunflower Helianthus annuus L. succeeding potato Solanum tuberosum L. Journal of Research, Punjab Agricultural University 31(3): 276-279.

8. Khot MM \& Patil RS (2002). Effect of Phosphorus and Nitrogen Fertilization on Sunflower (Helianthus annus L.) Nitrogen Uptake and Yield. Journal of Agronomy and Crop Science 188(4): 267-274.

9. Bakhsh I, Awan IU \& Baloch MS (1999). Effect of Various Irrigation Frequencies on the Yield and Yield Components of Sunflower. Pakistan Journal of Biological Sciences 2 (1): 194-195.

10. Prasad UK, Yadva VK, Prasad TN, Kumar A, Prasad SM (2001). Effect of irrigation and nitrogen on oil percentage, yield and water-use efficiency of winter sunflower (Helianthus annuus). Indian Journal of Agronomy 46(1): 171-176.

11. Taha M, Mishra BK \& Acharya N (2001). Effect of irrigation and nitrogen on yield and yield attributing characters of sunflower. Annals of Agricultural Research 22(2): 182-186.

12. Khazaie S, Shivay YS \& Kumar D (2008). Productivity and nutrient uptake of spring sunflower (Helianthus annuus) as influenced by nitrogen sources, sulphur and boron levels. Indian Journal of Agricultural Sciences 78(1): 90-94. 